gations of a fundamental nature, which have considerable potential use in the stereoselective elaboration of organic molecules. His appointment coincides happily with the fruitful expansion of these investigations and with his new department's move to its palatial new quarters in the noar future.

\section{Royal Military College of Science, Shrivenham :} Prof. A. Charlesby

Dr. Arthur Charlesby, who has been appointed professor of physics at the Royal Military College of Science, Shrivenham, is forty-one years of age, and was educated in London and at the Royal Atheneum, Antwerp, and the University of London, where he obtained a Ph.D. in 1939, and where he was afterwards engaged in research and teaching until 1942. After a period in the scientific research department at the Ministry of Aircraft Production he served with the R.A.F. until 1945, during which time he was engaged on operational rosearch into the scientific aspects of aerial warfare in the Mediterranean. During 194954 he was a principal scientific officer at the Atomic Energy Research Establishment, Harwoll, where he was in charge of a group studying the effects of atomic radiation on materials. He obtained a D.Sc. in 1954. For the past two years he has beon head of the Radiation Department of Tube Investments Research Laboratories. He has written numerous papers on solid state and nuclear subjects and is the editor of an international series of books on the effects of atomic radiation.

\section{Prof. A. D. S. Carter}

Prof. Alfred Denis Snowdon Carter, who has been appointed professor of mechanical engineering at Shrivenham, is thirty-five years of age, and was educated at Neath Intermediate School and at the University of Wales. After short periods of research at the Royal Aircraft Establishment and with Power Jets (Research and Development), Ltd., he joined the National Gas Turbine Establishment in 1946, since when he has been working on aerodynamic and vibration problems connected with the gas turbine. $\mathrm{He}$ has published many papors on blade theory and performance, on the axial compressor, and on vibra. tion problems associated with the gas turbine. Prof. Carter is a member of various Government scientific committees and an active member of the Institution of Mechanical Engineers; during 1952-55 he was a member of the Council of the Institution.

Prof. A. Lee

Prof. Alan Lee, who has been appointed professor of electrical engineering (radar and telecommunications) at Shrivenham, is fifty years of age, and was educated at Todmorden Grammar School and at Emmanuel College, Cambridge, where he read mathematics and mechanical sciences. After a short period of research in industry and teaching at the R.A.F. Electrical Wireless School, Cranwell, he joined the Royal Military College of Science in 1935. He has been head of the Radar and Telecommunications Branch since 1941. He has been a member of number of Government committees connected with his subject.

Advisory Council

The following have been appointed to the Advisory Council of the Royal Military College of Science to replace members whose terms of office had expired : Prof. J. Diamond, of the University of Manchester ;
Prof. M. H. L. Pryce, of the University of Bristol ; and Mr. R. P. Bell, of Balliol College, Oxford.

\section{Laboratory of Cryptogamic Botany, University of Manchester : Mr. E. Ashby}

AFter forty-seven years of service as chief steward and technician in the Laboratory of Cryptogamic Botany of the University of Manchester, Mr. Ernest Ashby will retire on November 25. He joined the laboratory soon after the appointment of Prof. W. H. Lang as the first occupant of the Barker chair of cryptogamic botany and continued with Prof. C. W. Wardlaw on his appointment in 1940. Over this long period, Mr. Ashby's talents for growing plants, often of a difficult and wayward nature, and for preparing materials for microscopic study, have been of great value in the research and teaching activities of the laboratory; and many have gratefully acknowledged his help. Perhaps most of all, his love of photography and photomicrography, and his zost for the achievement of perfection in them, have made a notable contribution to botanical illustration. The value of his work was recognized during the year by the conferment upon him by the University of the honorary degree of Master of Science. His many friends and associates have welcomed this signal honour and will wish him well in his retirement.

\section{Royal Society Antarctic Expedition : \\ Mr. Joseph MacDowall}

Mr. Joseph MacDowall has beon appointed leader of the Royal Society International Geophysical Year Antarctic Expedition at Royal Society Base, Halley Bay, from January 1958 until the party returns to the United Kingdom in the spring of 1959. He succeeds Col. Robin Smart, R.A.M.C., the present leader, who accepted the appointment only for the current year. Mr. MacDowall, who was seconded to the expedition from the Meteorological Office, Air Ministry, where he holds the rank of senior scientifie officer, is aged thirty-one. $\mathrm{H}_{\Theta}$ was educated at Wallasey Grammar School and served in the Royal Naval Air Arm during 1946-48. For the next threo years he studied at St. John's College, Cambridge, and then joined the Meteorological Office, where he worked at Kew Observatory and in the Instrument Division. Mr. MacDowall went to Halley Bay in November 1956 as leader of the meteorological and geomagnetic group which has been responsible for making the surface and upper air meteorological observations at Halley Bay since the International Geophysical Year began on July 1, 1957, together with observations of the Earth's magnetism and the accumulation of ice and snow in past years.

\section{Orbit of the Second Artificial Earth Satellite}

THe time of launching of the second Russian artificial Earth satellite is as yet unknown, but it was first detected in Britain with the Cambridge radio interferometer on November $3 \mathrm{~d} .05 \mathrm{~h} .58 \mathrm{~m}$. The satellite has been observed since then both visually and by radio methods. An orbit telegraphed to the British Astronomical Association from Coponhagen (Brit. Astron. Assoc. Circular, No. 391; Novomber 8, 1957) gives equatorial eloments computed by Cunningham for epoch Novomber 4.0:

$$
\begin{aligned}
& M \quad 151^{\circ} \quad \Phi \quad 6^{\circ} 02^{\prime}(5 \cdot 0 \cdot 10.5) \\
& \begin{array}{lrll}
\omega^{\prime} & 44 & 9 & 6 \\
a^{\prime} & 118 & 1.143
\end{array} \\
& \Omega^{\circ} \quad 118 \quad \text { Daily change in } \omega^{\prime}+0 \cdot 6^{\circ}
\end{aligned}
$$

